\title{
DEFOLIATION LEVELS AT VEGETATIVE AND REPRODUCTIVE STAGES OF SOYBEAN CULTIVARS WITH DIFFERENT RELATIVE MATURITY GROUPS ${ }^{1}$
}

\author{
MURILO MIGUEL DURLI ${ }^{2}$, LUIS SANGOI ${ }^{2}$, CLOVIS ARRUDA SOUZA $^{2 *}$, LUCIELI SANTINI LEOLATO $^{2}$, THAIS \\ LEMOS TUREK $^{2}$, HUGO FRANCOIS KUNESKI ${ }^{2}$
}

\begin{abstract}
Soybean tolerance to defoliation may be affected by relative maturity group (RMG) of the cultivar. For this reason, this study was carried out to evaluate the effects of artificial defoliation at vegetative and reproductive stages on the agronomic performance of soybean cultivars with different RMG. Two experiments were carried out in greenhouse conditions in Lages, Santa Catarina State, Brazil. Defoliation was carried out at V6 in the first experiment and at R3 in the second experiment. Three cultivars with contrasting RMG were used: BMX Veloz (RMG of 5.0, indeterminate growth habit), NA 5909 (RMG of 5.9, indeterminate growth habit), and TMG 7262 (RMG of 6.2, semi-determinate growth habit). Each cultivar was submitted to five defoliation levels: $0.0,16.6,33.3,50.0$, and $66.6 \%$. Leaf expansion after defoliation, grain yield and its components were determined. The BMX Veloz showed lower leaf expansion capacity and lower grain yield when compared to the other cultivars when defoliated at V6. Grain yield of the three cultivars only showed significant decreases with defoliation levels higher than $16.6 \%$ at R3. The cultivar BMX Veloz is less tolerant to defoliation during the vegetative stage when compared to the cultivars NA 5909 and TMG 7262. Cultivar maturity group does not interfere with soybean tolerance to defoliation at the reproductive stage in greenhouse conditions.
\end{abstract}

Keywords: Glycine $\max$ L. Merril. Leaf area. Source-sink relationship. Yield.

\section{NÍVEIS DE DESFOLHA NAS FASES VEGETATIVA E REPRODUTIVA DE CULTIVARES DE SOJA COM DIFERENTES GRUPOS DE MATURAÇÃO RELATIVA}

RESUMO - A tolerância da soja à desfolha pode ser afetada pelo grupo de maturação relativa (GMR) da cultivar. Este trabalho foi conduzido objetivando avaliar os efeitos da desfolha artificial nas fases vegetativa e reprodutiva sobre o desempenho agronômico de cultivares de soja com diferentes grupos de maturação. Foram conduzidos dois experimentos em casa de vegetação, no município de Lages, SC. No primeiro a desfolha foi realizada em V6 e no segundo em R3. Avaliaram-se três cultivares com grupos de maturação relativa (GMR) contrastantes: BMX Veloz (GM 5.0, hábito de crescimento indeterminado), NA 5909 (GM 5.9, hábito de crescimento indeterminado) e TMG 7262 (GM 6.2, hábito de crescimento semideterminado). Cada cultivar foi submetida a cinco níveis de desolha: $0 \%, 16,6 \%, 33,3 \%, 50 \%$ e 66,6\%. Avaliou-se a expansão foliar após a desfolha, o rendimento de grãos e seus componentes. A cultivar BMX Veloz apresentou menor capacidade de expansão foliar e menor rendimento de grãos do que as demais cultivares quando desfolhada em V6. O rendimento de grãos das três cultivares somente sofreu decréscimos significativos com desfolhas superiores a $16,6 \%$ em R3. Portanto, a cultivar BMX Veloz é menos tolerante à desfolha na fase vegetativa do que as cultivares NA 5909 e TMG 7262. O grupo de maturação da cultivar não interfere na tolerância da soja à desfolha na fase reprodutiva sob condições de casa de vegetação.

Palavras-chave: Glycine max L. Merril. Área Foliar. Relação fonte-dreno. Rendimento.

\footnotetext{
*Corresponding author

${ }^{1}$ Received for publication in 10/23/2019; accepted in 04/07/2020.

Paper extracted from the thesis of the first author.

${ }^{2}$ Department of Agronomy, Universidade do Estado de Santa Catarina, Lages, SC, Brazil; murilodurli@gmail.com - ORCID: 0000-00024672-9687, luis.sangoi@udesc.br - ORCID: 0000-0002-9102-4248, souza clovis@yahoo.com.br - ORCID: 0000-0003-0037-1509, lucieli.leolato@gmail.com - ORCID: 0000-0002-7688-4039, thaisturek@yahoo.com.br - ORCID: 0000-0002-9111-9001, hugokuneski@outlook.com - ORCID: 0000-0003-3268-020X.
} 


\section{INTRODUCTION}

Defoliating caterpillars, such as Anticarsia gemmatalis and Chrysodeixis includens, are biotic agents that reduce soybean (Glycine max) yield in Brazil, causing economic damage to the crop, from plant emergence to physiological maturation (GRIGOLLI, 2015). Defoliation has different effects on yield; depending on plant development stage, it occurs more intensely (OWEN et al., 2013). Some soybean cultivars have a great ability to recover from significant levels of defoliation without yield reduction, when it occurs at the vegetative stages of the crop or in agricultural seasons with good rainfall distribution (MOSCARDI et al., 2012).

To determine the critical attack periods of defoliating insects and establish criteria for using insecticides, the economic injury level (EIL) was determined. In Brazil, tolerance levels to defoliation were defined in the 1970s, 1980s, and 1990s, based on genotypes grown in those periods. Soybean cultivars used in the last century were predominantly late-cycle and with a determinate growth habit (BUENO; BATISTELA; MOSCARDI, 2010). These cultivars recovered well from severe defoliation before flowering (GLIER et al., 2015). After flowering, tolerance to leaf area reduction was lower. Based on studies with old cultivars conducted by Panizzi (1977) and Gazzoni and Moscardi (1998), EILs of 30 and $15 \%$ of defoliation were established for vegetative and reproductive stages, respectively.

Soybean cultivars currently used are different from those cultivated in the last century, when EILs were determined. They are earlier, have lower plant height, smaller leaf area, and higher productive potential (PROCÓPIO et al., 2013). These morphological and physiological changes in plants have raised questions about the adequacy of the proposed EILs for modern soybean crop production, as well as doubts about whether this mismatch may be the reason why integrated pest management is not fully adopted in the field (BUENO; BATISTELA; MOSCARDI, 2010).

In addition, cultivars with different maturity groups differ in their agronomic characteristics, which may affect plant response to defoliation levels and period of occurrence of defoliation (GLIER et al., 2015). Soybean cultivars with a low relative maturity group have a shorter growth cycle and smaller leaf area, and these traits may enhance their sensitivity to stresses. Conversely, cultivars with indeterminate growth habit and a high relative maturity group may be less prone to leaf area reduction because they have more time to expand new leaves after facing stress (ZANON et al., 2015).

Thus, it is important to assess the tolerance to defoliation of contemporary soybean cultivars with contrasting cycles since several genotypes are currently cultivated in producing regions of Brazil. This study was conducted based on the hypothesis that cultivars with small RMG are more sensitive to defoliation. The aim of this study was to evaluate the effects of artificial defoliation at vegetative and reproductive stages on the agronomic performance of soybean cultivars with different relative maturity groups.

\section{MATERIAL AND METHODS}

Two experiments were carried out in greenhouse conditions during the 2016/2017 crop season, in Lages, Santa Catarina State, Brazil, whose geographical coordinates are $27^{\circ} 52^{\prime} 10^{\prime \prime} \mathrm{S}$ and $50^{\circ}$ $18^{\prime} 15^{\prime}$ 'W. In each experiment, three cultivars with different maturity groups (MG) were used: BMX Veloz RR with RMG of 5.0 and indeterminate growth habit, NA 5909 RG with RMG of 5.9 and indeterminate growth habit, and TMG 7262 RR with RMG of 6.2 and semi-determinate growth habit. The cultivation of the three cultivars is very important in the South of Brazil. The greenhouse was maintained at $25 \pm 10^{\circ} \mathrm{C}$ day/night, with relative air humidity of approximately $70 \%$ during the experimental period.

The experiment used a randomized block design with three replications. A factorial design $(3 \times$ 5) was used for distributing the treatments. Each of the three cultivars was submitted to five defoliation levels, equivalent to 0.0 (control), 16.6, 33.3, 50.0, and $66.6 \%$ of the leaf area of the crop at the time of leaf removal. The level of $16.6 \%$ was equivalent to the EIL currently proposed for the reproductive stage, $33.3 \%$ to the EIL proposed for the vegetative stage, and 50.0 and $66.6 \%$ to values above the EIL in any crop development stage. Each experiment consisted of 45 experimental units represented by PVC pots with $5 \mathrm{~L}$ capacity. In the first experiment, defoliation was carried out at V6 stage (six nodes in the main stem with developed leaf, the end of vegetative period for cultivars with low RMG). In the second experiment, defoliation was performed at the R3 stage (beginning of pod formation, an important stage to determine the number of pods produced per plant), according to the phenological scale proposed by Ritchie, Hanway and Thompson (1982). Both experiments were sowed on the same day. Defoliation was performed using a pair of scissors for cutting the leaves longitudinally (Figure 1).

Sowing was carried out on November 1, 2016, with five seeds per pot. Each pot was filled with clayed soil classified as Nitossolo Vermelho distrófico previously submitted to a $5 \mathrm{~mm}$ mesh sieve. Seeds were treated with cyantraniliprole + thiamethoxam (Fortenza Duo ${ }^{\circledR}$ ). On the day of sowing, seeds were inoculated with the inoculant composed of stirpes Semia 5079 (Bradyrhizobium japonicum) and Semia 5019 (Bradyrhizobium elkanii) Masterfix Soja ${ }^{\circledR}$. After emergence, thinning was carried out and one plant was maintained per 
pot. Fertilization was performed with $660 \mathrm{~g} \mathrm{dm}^{-3}$ triple superphosphate and $660 \mathrm{~g} \mathrm{dm}^{-3}$ potassium chloride per pot, as recommended by Soil Chemistry and Fertility Commission (CQFS, 2016) for a yield of $6,000 \mathrm{~kg} \mathrm{ha}^{-1}$. Phytosanitary management was carried out with the insecticide lambda-cyhalothrin + chlorantraniliprole (Ampligo ${ }^{\circledR}$ ) and the fungicides azoxystrobin + benzovindiflupir $\left(\right.$ Elatus $\left.^{\circledR}\right)$ and trifloxystrobin + prothioconazole $\left(\right.$ Fox $\left.^{\circledR}\right)$. Applications of the insecticide and the fungicides started at the V5 stage, with preventive sequential applications every 14 days in order to prevent pests and diseases from affecting crop leaf area.

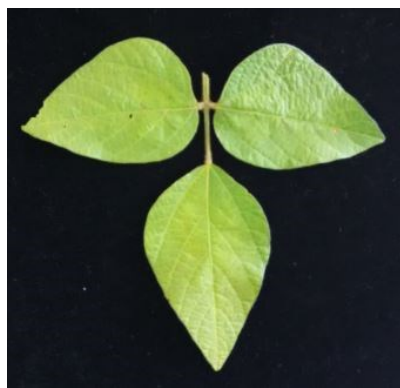

$0.0 \%$ Control

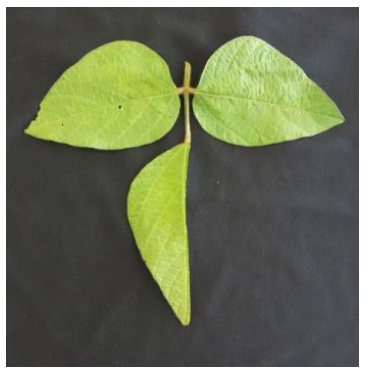

$16.6 \%$ of defoliation

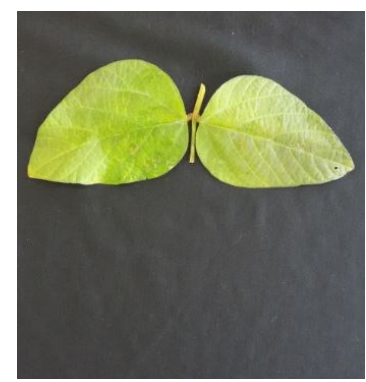

$33.3 \%$ of defoliation

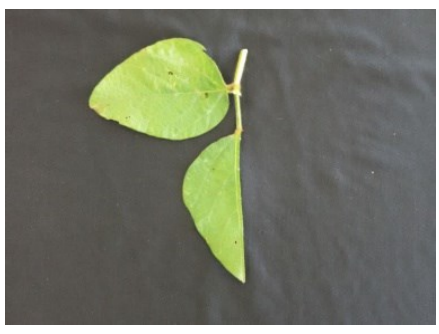

$50 \%$ of defoliation

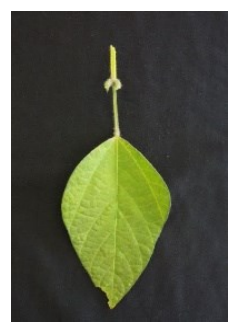

$66.6 \%$ of defoliation

Figure 1. Schematic representation of the five defoliation levels imposed on three soybean cultivars at V6 and R3.

Leaf area was determined by measuring the length and width of the central leaflet of each trifoliolate leaf of the plants and applying the equation of Richter et al. (2014): $\mathrm{LA}=\mathrm{a} \times \mathrm{L} \times \mathrm{W}$, where LA is leaf area $\left(\mathrm{m}^{2}\right)$, a is the angular coefficient (2.0185), L is leaf length $(\mathrm{m})$, and $\mathrm{W}$ is the largest leaf width (m). The first leaf area evaluation was carried out on the day of defoliation for both experiments (V6 and R3 stages). The second leaf area evaluation was carried out at the R2 (full flowering) and R5 (beginning of grain filling) stages, for the experiments with defoliation at V6 and R3, respectively. Leaf expansion was estimated indirectly by the difference in leaf area between V6 and $\mathrm{R} 2$ or between R3 and R5.

Harvest was carried out on April 4, 2017. After harvesting, the following determinations were carried out: number of pods per plant, number of grains per pod, number of grains per plant, 1000 grain weight (TGW), and grain yield per plant. Data were submitted to analysis of variance using the Ftest. $\mathrm{F}$ values for the main effects and interactions were considered as significant at 5\% significance level $(p<0.05)$. When statistical significance was reached by the F-test, the means of the qualitative factor (cultivar) were compared by the T-test and those of the quantitative factor (defoliation levels) were compared by polynomial regression. Both comparisons were performed at a significance level of $5 \%(\mathrm{p}<0.05)$.

\section{RESULTS AND DISCUSSION}

Table 1 shows the $F$ values and their significance levels for the variables evaluated in the experiment. Leaf area measured at R2 for the experiment with defoliation at V6 was affected by the main effect of defoliation. It presented a linear decrease as a function of the increase in defoliation percentage, regardless of the cultivar (Figure 2A). A similar result was found in the leaf area measured at R5 for the experiment with defoliation at R3 (Figure 2B). There was a reduction of $70 \mathrm{~cm}^{2}$ in the average leaf area of the three cultivars at R2 for every $10 \%$ of leaf area removed at V6. The decrease rate measured at R5 was $270 \mathrm{~cm}^{2}$ for every $10 \%$ defoliation. The values of leaf area measured at R5 were higher and the decrease rates were more pronounced when compared to R2. 
M. M. DURLI et al

Table 1. F values and their significance levels for the variables evaluated in the experiments.

\begin{tabular}{|c|c|c|c|c|c|c|c|}
\hline $\begin{array}{l}\text { Source of } \\
\text { Variation }\end{array}$ & G. L. & $\begin{array}{c}\text { LA R2 (def in } \\
\text { V6 and R5 } \\
\text { (def in R3) }\end{array}$ & $\begin{array}{c}\text { Leaf } \\
\text { expansion } \\
\text { (V6 to R2) } \\
\text { (R2 to R5) }\end{array}$ & Grain yield & $\begin{array}{c}1000 \text { grain } \\
\text { weight }\end{array}$ & $\begin{array}{c}\text { Number of } \\
\text { pods per } \\
\text { plant }\end{array}$ & $\begin{array}{c}\text { Number of } \\
\text { grains per } \\
\text { pod }\end{array}$ \\
\hline & \multicolumn{7}{|c|}{ Experiment with defoliation at V6 } \\
\hline Cultivar (C) & 2 & $22.0756^{* *}$ & $16.21 * *$ & $164.64 * *$ & $79.17 * *$ & $52.57 * *$ & $0.40 \mathrm{~ns}$ \\
\hline $\begin{array}{l}\text { Defoliation } \\
\text { (D) }\end{array}$ & 4 & $10.63 * *$ & $0.12 \mathrm{~ns}$ & $35.31 * *$ & $75.48 * *$ & $3.28 *$ & $1.49 \mathrm{~ns}$ \\
\hline $\mathrm{C} \times \mathrm{D}$ & 8 & $0.82 \mathrm{~ns}$ & $0.79 \mathrm{~ns}$ & $3.41 * *$ & $5.89 * *$ & $1.28 \mathrm{~ns}$ & $0.23 \mathrm{~ns}$ \\
\hline Blocks & 2 & $1.38 \mathrm{~ns}$ & $0.18 \mathrm{~ns}$ & $2.79 \mathrm{~ns}$ & $0.88 \mathrm{~ns}$ & $2.64 \mathrm{~ns}$ & $0.65 \mathrm{~ns}$ \\
\hline Error & 28 & & & & & & \\
\hline \multirow[t]{2}{*}{ Total } & 44 & & & & & & \\
\hline & \multicolumn{7}{|c|}{ Experiment with defoliation at R3 } \\
\hline Cultivar (C) & 2 & $213.21^{* *}$ & $114.52 * *$ & $70.93 * *$ & $66.16^{* *}$ & $63.23 * *$ & $2.61 \mathrm{~ns}$ \\
\hline $\begin{array}{l}\text { Defoliation } \\
\text { (D) }\end{array}$ & 4 & $9168 * *$ & $5.85^{* *}$ & $39.29 * *$ & $61.62 * *$ & $18.54 * *$ & $0.34 \mathrm{~ns}$ \\
\hline$C \times D$ & 8 & $8.31 * *$ & $2.05 \mathrm{~ns}$ & $1.50 \mathrm{~ns}$ & $2.17 \mathrm{~ns}$ & $4.01 * *$ & $0.82 \mathrm{~ns}$ \\
\hline Blocks & 2 & $9.51 * *$ & $0.43 \mathrm{~ns}$ & $0.52 \mathrm{~ns}$ & $1.11 \mathrm{~ns}$ & $0.96 \mathrm{~ns}$ & $2.73 \mathrm{~ns}$ \\
\hline Error & 28 & & & & & & \\
\hline Total & 44 & & & & & & \\
\hline
\end{tabular}

**significant at the $1 \%$ probability level $(\mathrm{p}<0.01)$.

$*$ significant at the $5 \%$ probability level $(\mathrm{p}<0.05)$.

ns - not significant $(\mathrm{p}>0.05)$.

For the experiment with defoliation at V6, the leaf area increment (leaf expansion) between V6 and R2 was not significantly affected by defoliation levels (Tables 1 and 2). Therefore, defoliation intensity at V6 did not affect plant capacity to emit new leaves to compensate for damage caused by defoliation. A distinct result was found by Gazzoni and Moscardi (1998): plants from the old cultivar Paraná were able to emit a larger leaf area when submitted to 33 and $66 \%$ defoliation levels at V3 and $\mathrm{V} 8$, in comparison to the non-defoliated control. At this phenological stage, the cultivar TMG 7262 showed a higher capacity to expand new leaves than the cultivars BMX Veloz and NA 5909. This is possibly due to its later-maturity group, a characteristic that delays the beginning of flowering and provides a longer period for emitting new leaves (ZANON et al., 2015). In this sense, the numbers of days between defoliation and the beginning of flowering were 5, 13, and 19 days for the cultivars BMX Veloz, NA 5909, and TMG 7262, respectively.

When defoliation was performed at R3 stage, leaf expansion between R3 and R5 was significantly affected by the main effects of cultivar and defoliation levels (Table 1). The treatments with the highest defoliation levels (50.0 and 66.6\%) were those that presented a higher leaf expansion. The higher defoliation levels stimulated plants to emit a larger leaf area to compensate for these losses, causing the plant to allocate photoassimilates for this activity (LOPES; LIMA, 2015). The overlap between vegetative and reproductive stages in cultivars of indeterminate growth habit stimulates a greater sink of carbohydrates for leaf expansion of treatments with higher defoliation levels (ZANON et al., 2015). BMX Veloz showed higher leaf expansion than NA 5909 and TMG 7262 when defoliated at R3. 
Table 2. Leaf area increment (leaf expansion) of three soybean cultivars under different levels of defoliation at V6 and R3.

\begin{tabular}{|c|c|c|c|c|c|}
\hline \multirow{3}{*}{$\begin{array}{c}\text { Defoliation } \\
\text { (\%) }\end{array}$} & \multicolumn{4}{|c|}{ Cultivar } & \multirow{2}{*}{$\mathrm{CV} \%$} \\
\hline & BMX Veloz & NA 5909 & TMG 7262 & Average & \\
\hline & \multicolumn{5}{|c|}{ Leaf expansion between V6 and R2 $\left(\mathrm{m}^{2}\right)$ with defoliation at V6 } \\
\hline 0.0 & 0.104 & 0.110 & 0.156 & $0.123 \mathrm{~ns}$ & \multirow{5}{*}{14.55} \\
\hline 16.6 & 0.123 & 0.112 & 0.139 & 0.124 & \\
\hline 33.3 & 0.114 & 0.110 & 0.140 & 0.121 & \\
\hline 50.0 & 0.126 & 0.113 & 0.141 & 0.127 & \\
\hline 66.6 & 0.102 & 0.116 & 0.152 & 0.123 & \\
\hline Average & $0.110 \mathrm{~b}$ & $0.112 \mathrm{~b}$ & $0.146 \mathrm{a}$ & & \\
\hline
\end{tabular}

Leaf expansion between R3 and R5 $\left(\mathrm{m}^{2}\right)$ with defoliation at R3

\begin{tabular}{lllll}
0,0 & 0.146 & 0.059 & 0.050 & $0.085 \mathrm{~b}$ \\
16.6 & 0.116 & 0.054 & 0.039 & $0.069 \mathrm{c}$ \\
33.3 & 0.131 & 0.064 & 0.031 & $0.075 \mathrm{bc}$ \\
50.0 & 0.135 & 0.084 & 0.080 & $0.099 \mathrm{a}$ \\
66.6 & 0.161 & 0.057 & 0.074 & $0.097 \mathrm{a}$ \\
\hline Average & $0.138 \mathrm{a}$ & $0.063 \mathrm{~b}$ & $0.055 \mathrm{~b}$ & \\
\hline
\end{tabular}

*Averages followed by the same lowercase letter in the row or column do not differ significantly by the $\mathrm{T}$ test at the $5 \%$ probability $(\mathrm{p}<0.05)$. $\mathrm{ns}$ - not significant $(\mathrm{p}>0.05)$.
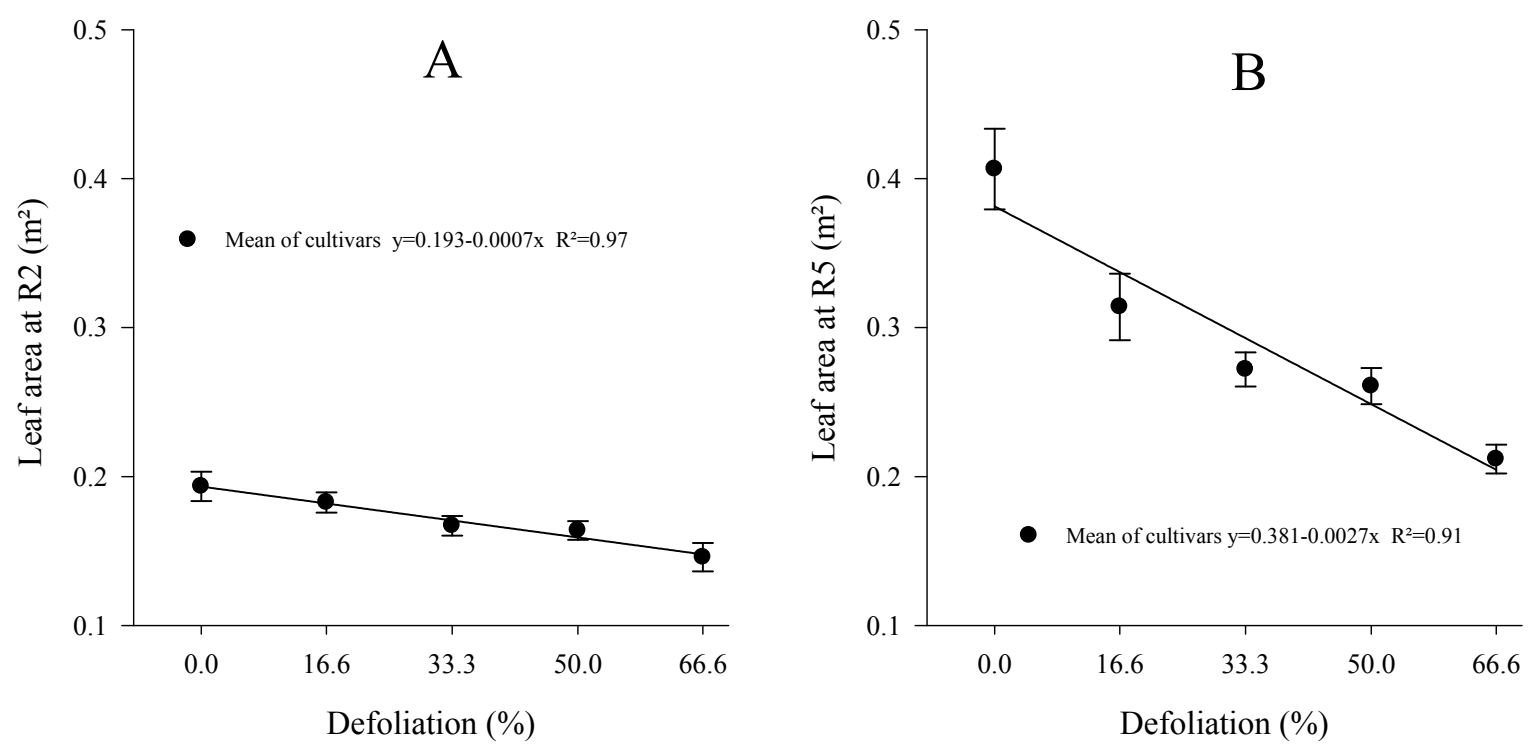

Figure 2. Leaf area of soybean at R2 when submitted to defoliation at V6 (A) and at R5 when submitted to defoliation at $\mathrm{R} 3$ (B). The vertical bars indicate the mean \pm standard error of the treatment. 
Grain yield per plant was affected by the interaction between cultivars and defoliation levels in the experiment in which the defoliation was carried out at the vegetative stage (Table 1). When defoliated at V6, the cultivar BMX Veloz linearly decreased grain yield as defoliation percentage increased (Figure 3A), decreasing approximately 1.0 $\mathrm{g}$ for each $10 \%$ reduction in leaf area. The cultivars NA 5909 and TMG 7262 responded quadratically to an increase in defoliation percentage, with decreases in grain yield with defoliations over $16.6 \%$.

When defoliation was carried out at R3, only the main effect of defoliation affected grain productivity (Table 1). No difference was found among the three cultivars in the response of grain yield per plant as a function of leaf area reduction intensity. This probably occurred because the period between R3 and physiological maturation was 48 days for all these genotypes. Regression analysis showed that the average yield of the three cultivars quadratically decreased as defoliation percentage increased, with the highest decreases registered from $16.6 \%$ reduction in leaf area onwards (Figure 3B).
Board et al. (2010) also found a similar response among cultivars with different RMG when submitted to defoliation at the reproductive stage. Decreases in productivity resulting from defoliation at the beginning of pod formation confirm the current information regarding tolerance to loss of soybean leaf area at the reproductive stage. This is evidence that sharp decreases in yield only occur with leaf area reductions above $15 \%$.

Cultivars with higher relative maturity group do not necessarily have a longer reproductive period. Their difference in comparison to short-cycle cultivars is mostly relative to duration of the vegetative stage (ZANON et al., 2015). The longer period until flowering of cultivars with a higher RMG provides them with more time to increase leaf area before the beginning of flowering. Therefore, this characteristic can enhance their tolerance to stress periods at the vegetative stage (EGLI, 2011). This is in accordance with the results found in our study, as a difference was found in the tolerance of cultivars to defoliation at V6.
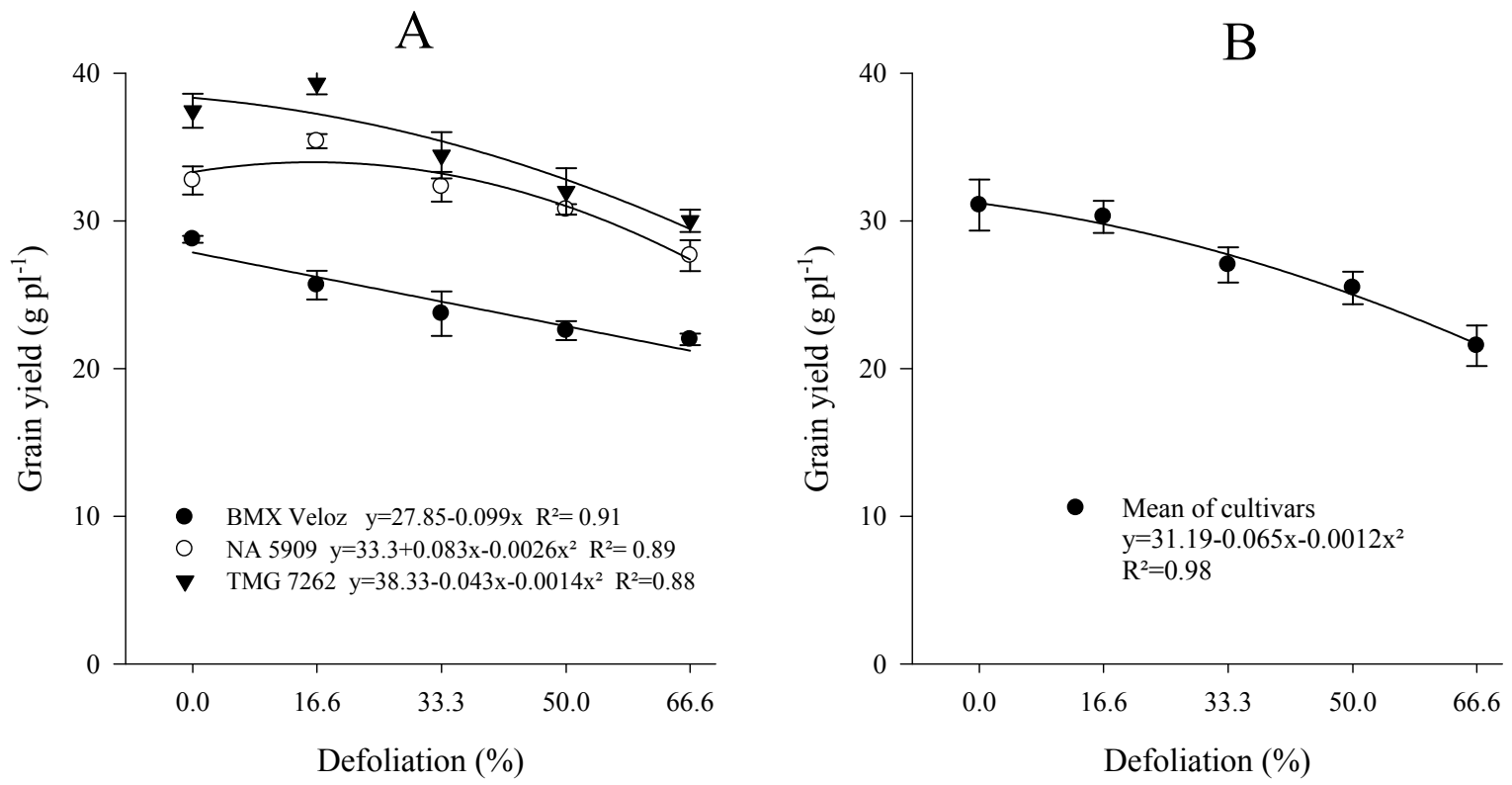

Figure 3. Grain yield per plant of soybean cultivars under different levels of defoliation at V6 (A) and R3 (B). The vertical bars indicate the mean \pm standard error of the treatment.

There are two sources of assimilates for grain filling in soybean: plant photosynthesis and remobilization of stored carbohydrates (KOESTER et al., 2014). The contribution of carbohydrates stored in leaves and petioles is low, not exceeding 15\% (EGLI, 2011). Therefore, plant photosynthetic activity from R3 to R7 is very important to determine soybean grain yield (HEIDEL; BRUN, 1983). The increase of sink tissues at the reproductive stages of soybean does not stimulate plants to increase their photosynthesis levels in the remaining leaves of the canopy (EGLI, 2011). Consequently, the loss of leaf area directly decreases plant photosynthetic capacity. Board and Kahlon (2011) found that the remaining leaves after defoliation failed in photosynthetically compensating the lost leaves. Thus, the loss in leaf area directly reduces the photosynthetic rate and may limit grain yield.

The data on grain yield per plant in (Figure 3) show that the tolerance to defoliation of the cultivars used in this study (released in the last decade) is 
lower than that of the cultivars used for a longer time in the market. At the vegetative stage, defoliation of up to $100 \%$ did not significantly affect grain yield in the old cultivars FT Abyara, Paraná and BRS 133 (PARCIANELLO et al., 2004; GAZZONI; MOSCARDI, 1998). At R3, old cultivars, such as BRS Favorita, were able to withstand 33 to $66 \%$ of defoliation without significant losses in grain yield (ZUFFO et al., 2015). Modern soybean cultivars are earlier, have lower leaf area, and have higher productive potential (PROCÓPIO et al., 2013). Such characteristics enhance their sensibility to leaf area reduction (ZANON et al, 2015). This behavior was more evident when the cultivar with low RMG (BMX Veloz) was defoliated at V6 (Figure 3A).

There was also variation in 1000 grain weight according to defoliation levels in both experiments and by the interaction between the factors cultivar and defoliation level in the experiment with defoliation at V6 (Table 1). In the experiment with defoliation at the vegetative stage, the cultivars Veloz and TMG 7262 had a linear reduction as a function of the increased defoliation level, with decreasing rates of $7.1 \mathrm{~g}$ for each $10 \%$ increase of removed leaf area. The cultivar NA 5909 had a quadratic reduction in 1000 grain weight as the defoliation level increased. In the experiment with defoliation at the reproductive stage, defoliation linearly decreased 1000 grain weight as defoliation percentage increased, regardless of the study cultivar. The average decrease rate was $4.9 \mathrm{~g}$ for each $10 \%$ increase in the percentage of removed leaf area. Leaf area values at R2 in the control treatment were $0.18 \mathrm{~m}^{2}, 0.18 \mathrm{~m}^{2}$ and $0.23 \mathrm{~m}^{2}$ for BMX Veloz, NA 5909 and TMG 7262, respectively.

Board and Kahlon (2011) attributed the decrease in 1000 grain weight caused by defoliation to a decrease in photoassimilate supply. The soybean cultivars currently used have smaller leaf area and higher productive potential (PROCÓPIO et al., 2013). Consequently, the supply of products derived from photosynthesis is lower when submitted to defoliation. In addition to that, the semi-determinate and indeterminate growth habit of the cultivars used in the trial stimulated a greater sink of carbohydrates for leaf expansion in treatments with higher defoliation levels at R3 (Table 1). The lower supply of photoassimilates decreased kernel mass and productivity, especially when leaf area reduction occurs at the reproductive stage, regardless of the cultivar maturity group (Figures $3 \mathrm{~B}$ and $4 \mathrm{~B}$ ). A different result was reported by Ribeiro and Costa (2000), who observed an increase in 1000 grain weight for defoliation at $\mathrm{R} 3$ in cultivars released in the last century. The authors attributed this behavior to the ability of those cultivars to store carbohydrates in order to compensate for leaf area loss.
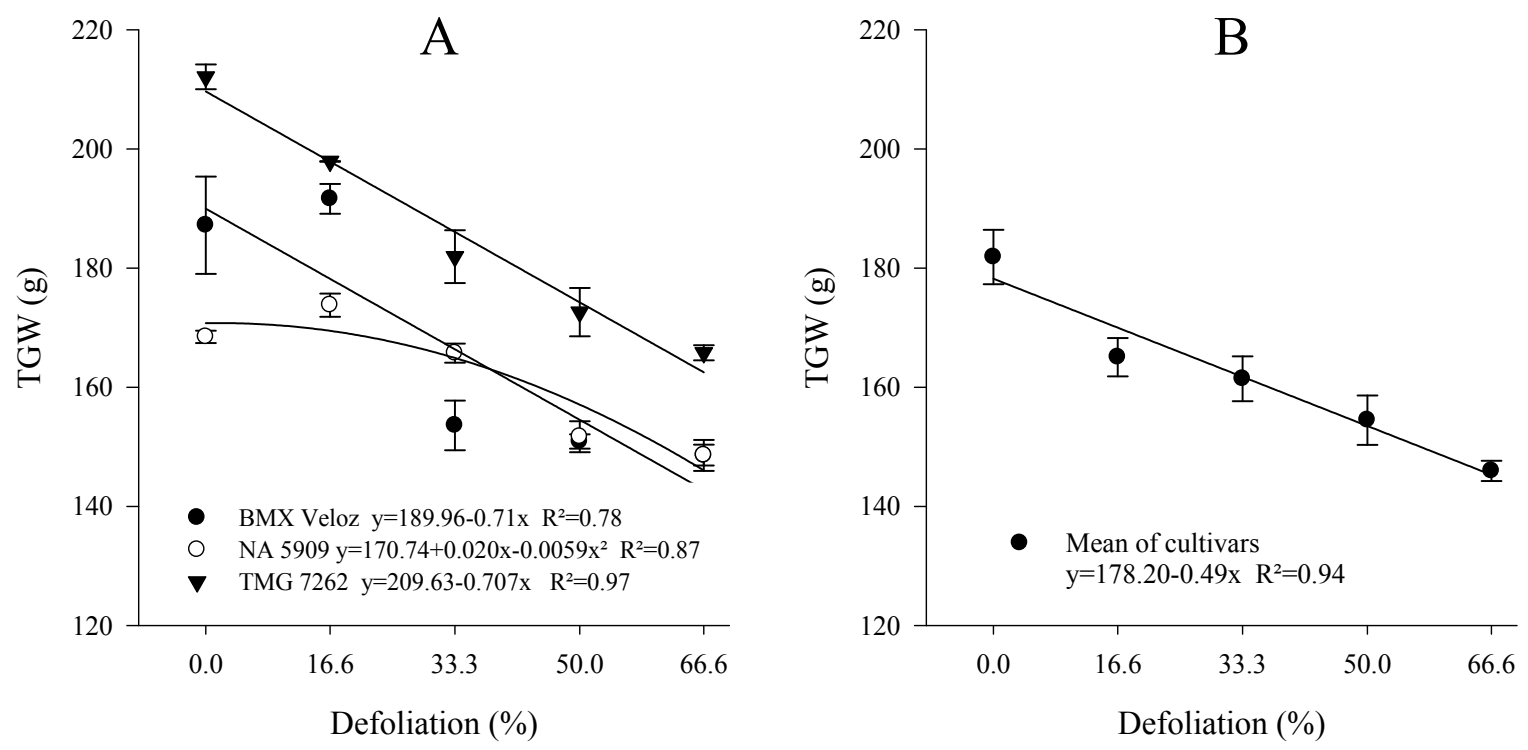

Figure 4. Thousand grain weight (TGW) of soybean cultivars under different levels of defoliation at V6 (A) and R3 (B). The vertical bars indicate the treatment mean \pm standard error of the treatment.

In the experiment with defoliation at V6, the main effect of defoliation affected the number of pods produced per plant (Table 1). There was a quadratic decrease for this variable as defoliation percentage increased, regardless of cultivar (Figure 5A). However, although the main effect of defoliation by the F-test and the quadratic model by regression analysis were significant, the difference in the average number of pods per plant of the three cultivars only ranged from 83 in the treatment without defoliation to 77 when $66.6 \%$ of the leaf area was removed at V6. Souza et al. (2014) did not find a significant difference in the number of pods per plant when defoliation occurred at V4 to V9. 
This behavior is due to the ability of soybean plants to produce new nodes and flower buds even when submitted to stresses at the vegetative stage (MOSCARDI et al., 2012), a characteristic that is more pronounced in cultivars with an indeterminate growth habit.

On the other hand, in the experiment with defoliation at R3, the number of pods per plant was affected by the interaction between cultivars and defoliation levels (Table 1). At this phenological stage, the cultivar NA 5909 presented a linear decrease because of an increase in defoliation percentage, while the cultivars TMG 7262 and BMX Veloz had a quadratic decrease with a reduction in leaf area. Defoliation carried out in plants at R3 promotes a rearrangement on yield components in order to maintain grain production. Thus, the plant aborts some pods and maintains those that are capable of translocating photoassimilates from the remaining leaves (SILVA et al., 2015). Because of an increase of sink tissues during the flowering and grain filling periods, peaks of photosynthetic activity occur so that the plant can fill the pods (BOARD et al., 2010). Defoliations occurring between R3 and R5 cause higher losses in the number of pods because there are not enough photoassimilates for the plant to fill all the pods, which causes their abortion.

According to Damasceno et al. (2019), soybeans have a great capacity to recover from defoliation at early stages of plant development. Significant reductions in grain yield only occur when there is intense defoliation, close to $100 \%$. Conversely, at the beginning of grain filling, long periods of severe defoliation significantly reduce the number of pods per plant, 100 -seed weight and crop grain yield.
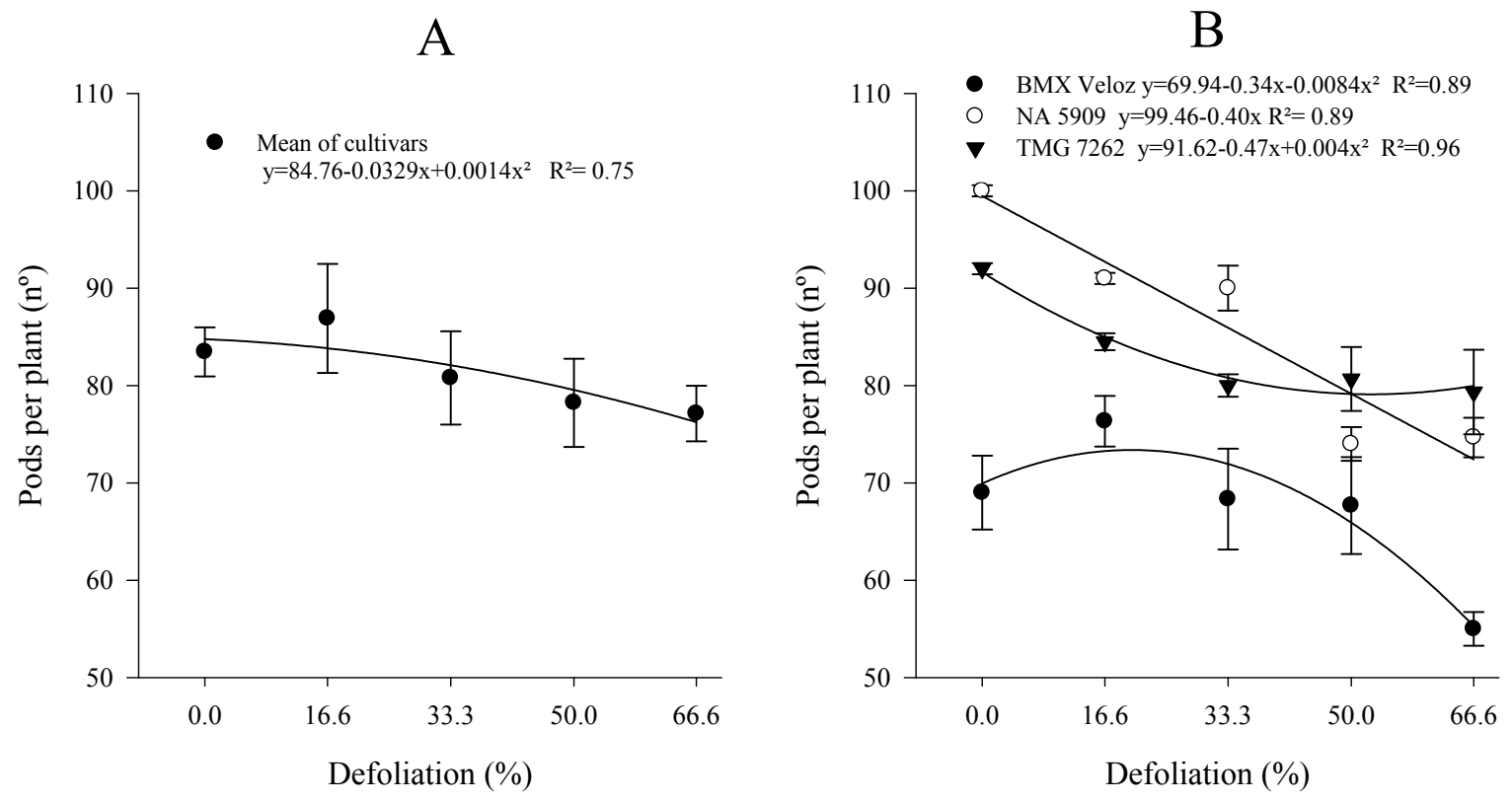

Figure 5. Number of pods per plant of soybean cultivars at different levels of defoliation at V6 (A) and R3 (B). The vertical bars indicate the means \pm standard error of the treatment.

Number of grains per pod ranged from 2.3 to 3.1. It was not affected by cultivar or defoliation level (Table 1). According to Zanon et al. (2015), number of grains per pod is the most stable soybean yield component, as it is less affected by cultivar, management practices and environmental conditions.

Collectively, the results of the present work showed that defoliation carried out at V6 reduced more grain yield of the cultivar BMX Veloz than of the cultivars NA 5909 and TMG 7262 as a result of its lower capacity to emit new leaves at the vegetative stage. This is an indication that the economic injury level of soybean at V6 may depend on cultivar maturity group. On the other hand, there was no significant interaction between cultivar and defoliation when stress was imposed at R3. Leaf area reductions of $16.6 \%$ carried out at the beginning of pod formation did not significantly reduce grain yield, regardless of cultivar maturity group. This information supports the current recommendation to control defoliating insects. It also indicates that the cultivar maturity group did not interfere with the economic threshold level of soybean submitted to defoliation at R3.

\section{CONCLUSIONS}

Grain yield of the cultivar with low RMG, BMX Veloz, is more sensible to defoliation at V6 than the yield of NA 5909 and TMG 262. 
The cultivar maturity group does not interfere with the response of BMX Veloz, NA 5909 and TMG 7272 to defoliation at R3, under greenhouse conditions.

\section{ACKNOWLEDGMENTS}

The authors are thankful to the Conselho Nacional de Desenvolvimento Científico e Tecnológico (CNPq/Universal 460983/2014-8), Coordenação de Aperfeiçoamento de Pessoal de Nível Superior/Programa de Apoio à Pós-graduação (CAPES/PROAP) and Fundação de Amparo à Pesquisa e Inovação do Estado de Santa Catarina (FAPESC/PAP/UDESC) for the financial support to carry out this experiment.

\section{REFERENCES}

BOARD, J. E. et al. Yield response of soybean to partial and total defoliation during the seed-filling period. Crop Science, 50: 703-712, 2010.

BOARD, J. E.; KAHLON, C. S. Soybean yield formation: what controls it and how it can be improved. In: EL-SHAMY, H. A. (Ed.) Soybean physiology and biochemistry. Rijeka, Croatia: IntechOpen, 2011. p. 1-36.

BUENO, A. F.; BATISTELA, M. J.; MOSCARDI, F. Níveis de desfolha tolerados na cultura da soja sem a ocorrência de prejuízos à produtividade. Londrina, PR: Embrapa Soja, 2010. 12 p. (Circular Técnica, 79)

COMISSÃO DE QUÍMICA E FERTILIDADE DO SOLO - RS/SC (CQFS-RS/SC). Manual de adubação e de calagem para os estados do Rio Grande do Sul e Santa Catarina. Porto Alegre, RS: SBCS - Núcleo Regional Sul/UFRGS, 2016. 396 p.

DAMASCENO, L. J. et al. Defoliation levels supported in soybean crop with no harm on productivity in the municipality of Parauapebas. Journal of Agricultural Science, 11: 227-234, 2019.

EGLI, D. B. Soybean yield physiology: principles and process of yield production. In: SINGH, G. (Ed.). The soybean: botany, production and uses. Wallingford, UK: CABI, 2011. p. 113-141.

GAZZONI, D. L.; MOSCARDI, F. Effect of defoliation on recovery of leaf area, on yield and agronomic traits of soybeans. Pesquisa Agropecuária Brasileira, 33: 411-424, 1998.
GLIER, C. A. S. et al. Defoliation percentage in two soybean cultivars at different growth stages. Revista Brasileira de Engenharia Agrícola e Ambiental, 19: $567-573,2015$

GRIGOLLI, J. F. J. Pragas de soja e seu controle. In: LOURENÇÃO, A. L. F. (Ed.). Tecnologias e produção: soja 2014/2015. Curitiba, PR: Midiograf, 2015. p. $98-124$.

HEIDEL, J. C.; BRUN, W. Light and shade effects on abscission and photoassimilate partitioning among reproductive structures in soybean. Plant Physiology, 73: 434-439, 1983.

KOESTER, R. P. et al. Historical gains in soybean (Glycine max Merril.) seed yield are driven by linear increases in light interception, energy conversion, and partitioning efficiencies. Journal of Experimental Botany, 65: 3311-3321, 2014.

LOPES, N. F.; LIMA, M. G. S. Fisiologia da Produção. Viçosa, MG: Ed. UFV, 2015. 492 p.

MOSCARDI, F. et al. Soybean response to different injury levels at early developmental stages. Ciência Rural, 42: 389-394, 2012.

OWEN, L. N. et al. Impact of defoliation on yield of group IV soybeans in Mississippi. Crop Protection, 54: 206-212, 2013

PANIZZI, A. R. Insetos da soja no Brasil Londrina, PR: Embrapa Soja, 1977, 20 p. (Boletim Técnico, 1).

PARCIANELLO, G. et al. Tolerância da soja ao desfolhamento afetada pela redução do espaçamento de fileiras. Ciência Rural, 34: 357-364, 2004.

PROCÓPIO, S. O. et al. Plantio cruzado na cultura da soja utilizando uma cultivar de hábito de crescimento indeterminado. Revista de Ciências Agrárias, 56: 319-325, 2013.

RIBEIRO, A. L. P.; COSTA, E. C. Desfolhamento em estádios de desenvolvimento da soja, cultivar BR 16, no rendimento de grãos. Ciência Rural, 30: 767771,2000

RICHTER, G. L. et al. Estimativa da área de folhas de cultivares antigas e modernas de soja por método não destrutivo. Bragantia, 73: 416-425, 2014.

RITCHIE, S. W.; HANWAY, J. J.; THOMPSON, H. E. (Ed.). How soybean plant develops, Ames, IA: Iowa State University of Science and Technology, Cooperative Extension Service, 1982. 20 p. (Special Report, 53). 
SILVA, A. F. et al. Correlation and path analysis of soybean yield components. International Journal of Plant, Animal and Environmental Sciences, 5: 177-179, 2015.

SOUZA, V. Q. et al. Caracteres morfofisiológicos e produtividade de soja em razão da desfolha no estádio vegetativo. Científica, 42: 216-223, 2014.

ZANON, A. J. et al. Desenvolvimento de cultivares de soja em função do grupo de maturação e tipo de crescimento em terras altas e terras baixas. Bragantia, 74: 400-411. 2015.

ZUFFO, A. M. et al. Agronomic performance of soybean according to stages of development and levels of defoliation. African Journal of Agricultural Research, 10: 2089-2096, 2015. 